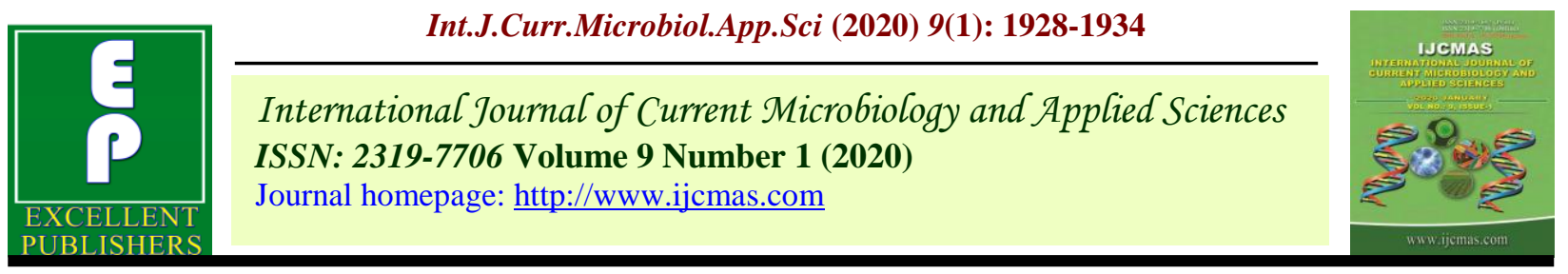

Original Research Article

https://doi.org/10.20546/ijcmas.2020.901.216

\title{
Running Mortality Syndrome (RMS)-A New Disease that Struck the Indian Shrimp Industry
}

\author{
Nanjala Veerabhadra Rao $^{1 *}$ and Avugaddi Satyanarayana ${ }^{2}$ \\ ${ }^{1}$ Fisheries Research Station, Sri Venkateswara Veterinary University, Undi, \\ West Godavari, A.P., India \\ ${ }^{2}$ Department of Zoology, Andhra University, Visakhapatnam, Andhra Pradesh, India \\ *Corresponding author
}

\begin{tabular}{|l|}
\hline Ke y w o r d s \\
RMS, L. vannamei, \\
$\begin{array}{l}\text { V. parahaemolyticus, } \\
\text { Vibrio azureus }\end{array}$ \\
\hline Article Info \\
\hline $\begin{array}{l}\text { Accepted: } \\
15 \text { December } 2019 \\
\text { Available Online: } \\
\text { 20 January } 2020\end{array}$ \\
\hline
\end{tabular}

A B S T R A C T

Infectious diseases are quiet common in shrimp culture operations. Apart from infectious diseases certain syndromes affecting the culture operations in the shrimp farms particularly from Andhra Pradesh and Tamil Nadu. Running mortality syndrome is such type syndrome associated with morbidity and mortality which leads to less productivity. In the present study we have examined the haemolymph and hepatopacreas of the infected shrimps. The results revealed that, the affected shrimp showed the higher percentage of Vibrio species such as Vibrio parahaemolyticus and Vibrio azureus. Histopathological studies also revealed that, high B cells in the hepatopancreas in the early stage of disease indicate the over feeding of shrimps. Running Mortality Syndrome is depicted be pond management associated syndrome rather than infectious in nature and thus can be overcome through best management practices.

\section{Introduction}

The Pacific white shrimp, Litopenaeus vannamei, is now the species of choice of shrimp farming industry in India because of its advantages in culture, viz., high tolerance of salinity, perennial high health seed availability, low protein requirement and high yield in short grow out period. Considering its advantages in commercial farming of Litopenaeus vannamei was permitted in India in the year 2009 by Coastal aquaculture authority (CAA). As per CAA guide lines, the imported specific pathogen free (SPF) brood stock from approved suppliers should be screened for all OIE (World Organization for Animal Health) listed shrimp viruses at Rajiv Gandhi Center for Aquaculture (RGCA) quarantine facility and then supplied to CAA registered hatcheries. Due to this the shrimp production of India has gone up from 1, $00,000 \mathrm{MT}$ in 2009 to 2, 70,000 MT in the year 2013. 
The term Vibriosis is used to refer to all the types of infections caused by the bacteria of the genus Vibrio including bacterial shell disease and black gill disease. Vibriosis is most frequently encountered in culture shrimps and majority of the stressed shrimps have the presence of vibrio species. Since vibrio species are opportunistic pathogens they attack stressed shrimps which lead to mass mortality (Baumann et al., 1984; Lavilla-Pitago et al., 1990; 1998). According to Kannapiran et al., (2009) as the pond is a confined environment and all the environmental parameters of the pond maintained as normal through the water exchange and the application of lime. Shrimps were used to undergo stress conditions due to unfavorable environmental conditions such as high stocking density, inadequate management of the culture pond.

According to Sung et al., (1999) in a condition a large number of virbrio increased in shrimp culture system, when shrimps were under stress conditions. In studies of Costa et al., (1998) reported that because of opportunistic behavior of most pathogenic vibrios they infect the penaeid shrimps and vibrio behave more like true pathogen than opportunistic. The entry of pathogenic type vibrio to the host through the hepatopancreas as it is the target organ of the most of the shrimp species as reported by Chen et al., (1992) and Frelier et al., (1992).

Another study conducted by Sung et al., (1999 \& 2001) suggested that prevalence of the diseases in shrimps were poorly connected to the increased number of vibrios in cultured systems, but strongly influenced on the growth of potentially pathogenic vibrio, in the pond water as well as in shrimp hepatopancreas.

Amaro et al., (1995) documented about the relationship between occurrence of the disease and pathogenic population in the vicinity of the surrounding water. According to Gomez-Gil et al., (1998) the diversity of vibrios were observed in healthy $P$. vanname $i$ and they have reported the presence of various species of vibrios throughout the culture. As no sudden increase of pathogenic species of vibrio, it indicates that these are a part of normal flora of the environment. Singh et al., (1998) provided information about the enhanced proliferation of the vibrios in culture system of $P$. indicus, with increased salinity of the pond water. According to Gopal et al., (2005) after the invagination of vibrio to the host it can develop and colonize in digestive tract of the host and turn as pathogenic. Gopal et al., (2005) also made a comparative study with water, sediment and shrimp samples collected from different shrimp ponds of East and West coast of India.

Even though the imported brood stock is specific pathogen free but with the continual expansion and intensification, the cultures were prone for infection by endemic viral diseases like white spot syndrome virus (WSSV) and Infectious hypodermal hematopoietic necrosis virus (IHHNV). However, so far there are no incidents of listed exotic viral infections of $L$. vannamei such as Infectious myonecrosis virus (IMNV), Taura syndrome virus (TSV) and Yellow head virus (YHV), until 2014. During March 2011, a new disease has struck the industry. The shrimps showed different symptoms, mortality patterns, which werenot similar to any of the reported diseases. Since then farmers has lost almost four crops. Up to $70 \%$ mortality was reported in most of the cases. Several farmers have closed down their operations especially in Nellore region of Andhra Pradesh.Thus, to differentiate from other diseases the present disease and basing on its symptomatic conditions, the observed new disease was named as Running Mortality Syndrome (RMS). 


\section{Materials and Methods}

Microscopic observation of wet mounts of pleopod show very high external fouling with filamentous bacteria and protozoa. Gut content analysis shows sloughed hepatocytes. More red pigment was noticed in the wet mount of Hepatopancreas. Samples were sent to RGCA laboratory at sirikhazi, Tamilnadu. Shrimp was tested negative for all the known viruses like WSSV, IHHNV, YHV, TSV, IMNV, HPV and MBV by PCR and RT-PCR. The infected shrimp shows delayed hemolymph clotting time. Mortality has not come down in spite of various treatments to lower the vibrio loads in the pond and shrimp gut by applying various sanitizers, Probiotics and organic acids. But high mortality is reported in shrimps associated with high Vibrio loads.

\section{Histopathological studies}

The shrimps with the characteristic symptoms were fixed in Davidson's fixative and tissue sections were stained with Harries hematoxylin and eosin. During early stages there are relatively more $\mathrm{B}$ and $\mathrm{R}$ cells in the tubules of Hepatopancreas (Figure 4). Later stages of disease show sloughing of hepatocytes (Figure 5) and light hemocytic inflammation with no symptoms of known enteric viruses. Few cells are exhibiting karyomegaly. High $B$ cells in the hepatopancreas in the early stage of disease indicate the over feeding of shrimps.

\section{Results and Discussion}

\section{Gross signs of RMS affected shrimp}

In the early stages of disease Litopenaeus vannamei, apparently started showing gross signs, which were characterized by the antennae cut and Uropods turned normal to red in color. Later on Hepatopancreas turns reddish yellow (Figure1) and finally entire body turns dark red in color (Figure 2). Continuous internal mortality is noticed throughout the day (Figure 3). The dead shrimps are settled at the bottom of the tank and will not come to sides or surface. Farmers will come to know about this only when dead and cannibalized shrimp come to check tray. The mortality is noticed irrespective of seed source. The occurrence of mortality is directly proportional to stocking density. Higher the stocking density early the mortality sets in. Mortality rate is relatively more in low saline ponds. White or yellow fecal matter is noticed in the gut. Mortality noticed only during intermoult stage. Very poor survival and high feed conversion ratios were reported at the time of harvest.

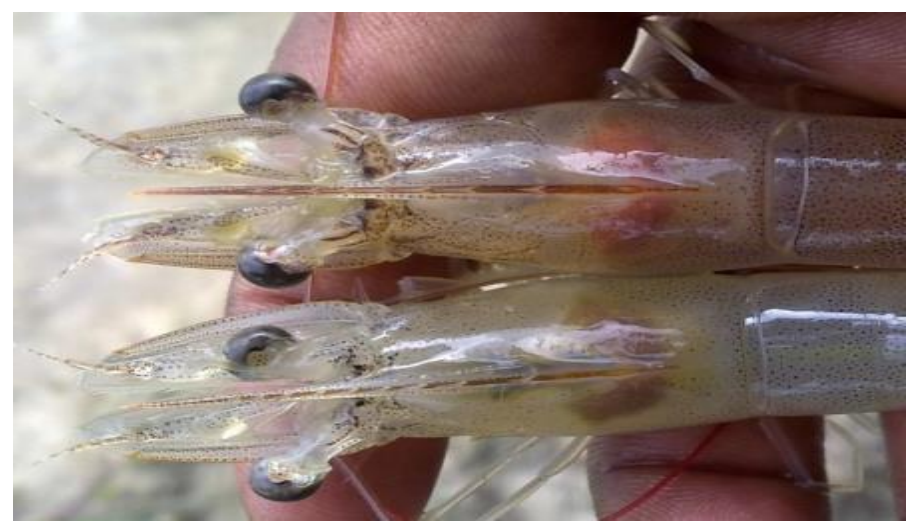

Figure.1 Reddish yellow Hepatopancreas during early stage of RMS 


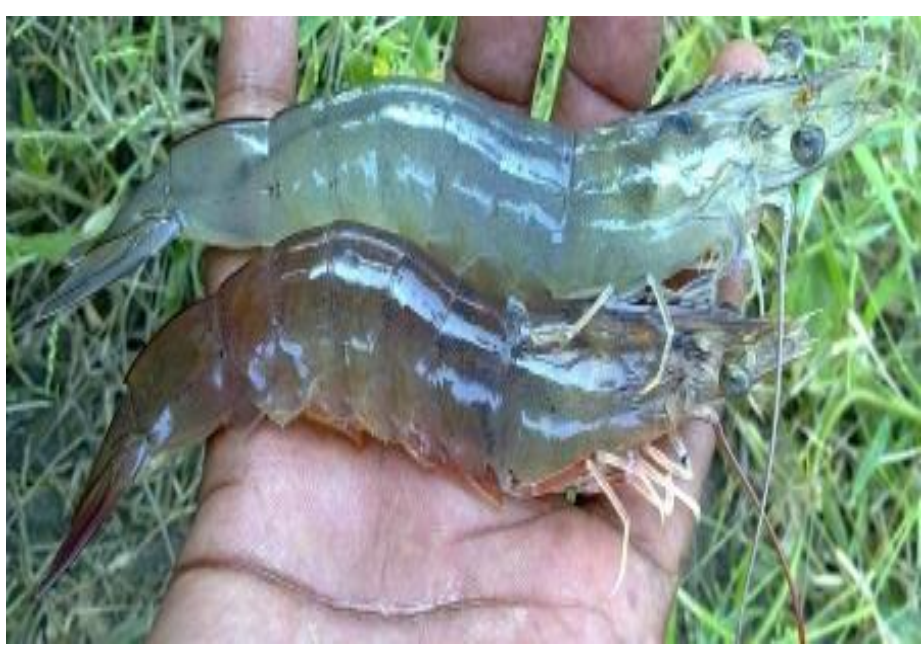

Figure.2 Showing upper normal and lower diseased shrimp

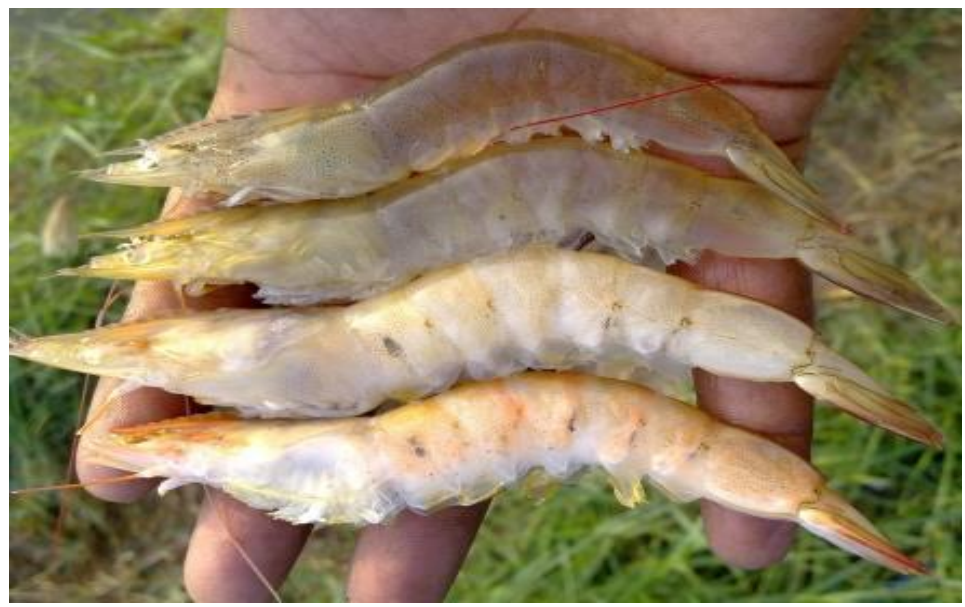

Figure.3 Dead shrimp samples due to prevalence of RMS, indicating continuous mortality There is no correlation to the known water quality parameters like $\mathrm{pH}$, Ammonia nitrogen, Nitrite nitrogen, Hydrogen sulphide low dissolved oxygen concentration and plankton

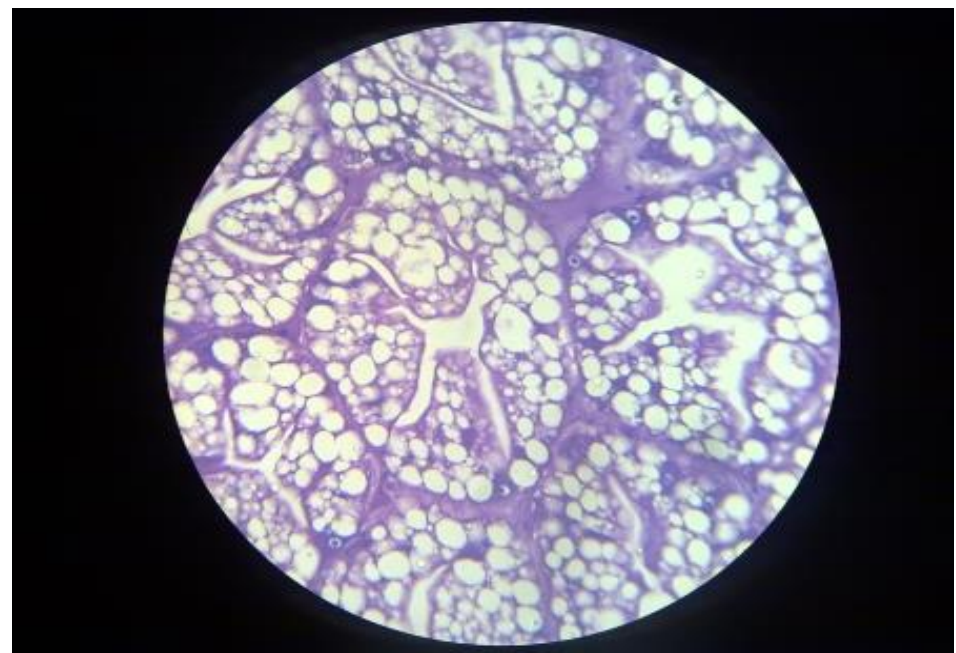

Figure.4 Histology of Hepatopancreas of RMS shrimps with more B and R Cells 


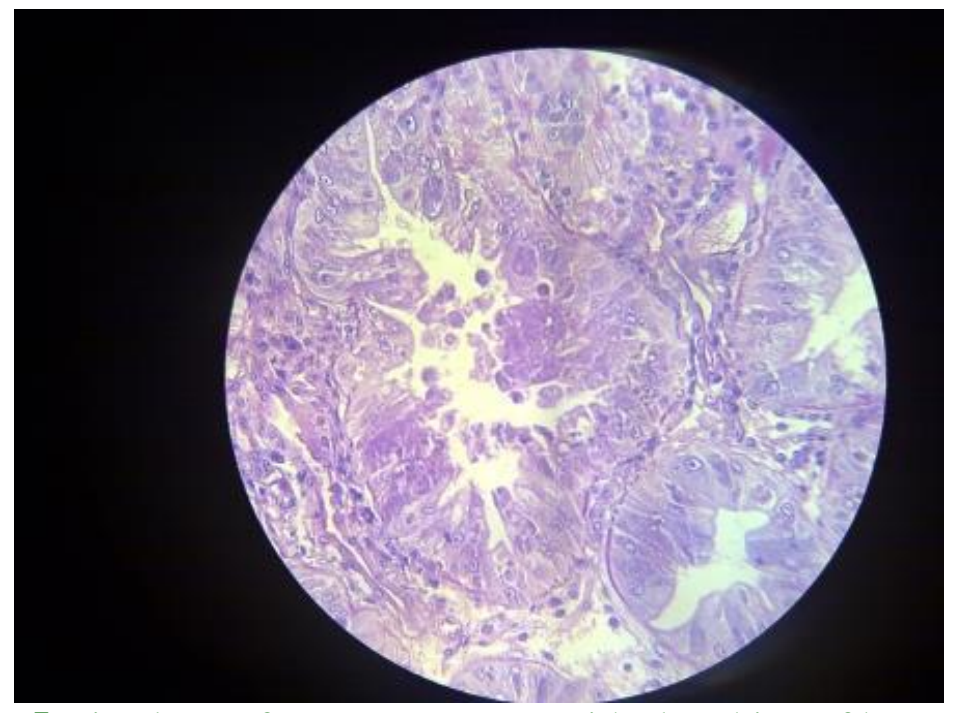

Figure.5 Histology of Hepatopancreas with sloughing of hepatocytes

There is no correlation to the known water quality parameters like $\mathrm{pH}$, Ammonia nitrogen, Nitrite nitrogen, Hydrogen sulphide low dissolved oxygen concentration and plankton.

\section{Management of disease}

In the beginning days, farmers managed this disease by regularly removing the dead shrimp from the pond. Reducing the stocking density by partial harvesting reduced the mortality. Reduced feed quantity or suspending feed for few days reduce the mortality. Some farmers opted for extensive culture and were able to reach the production up to 30 count without RMS. The culture practices like stocking bigger post larvae, reducing stocking density, nursery management, partial harvest, strict feed management and Polyculture with has reduced the incidence of RMS.

In conclusion, the intensive aquaculture practices have caused to increase the various sources of anthropogenic stress factors to aquatic ecosystems have led to the emergence of many new diseases in shrimp industry. High B cells in the hepatopancreas in the early stage of disease indicate over feeding.
Delayed Hemolymph clotting time and expansion of chromatophores indicates stress. Water exchange is reduced on biosecurity grounds. Recently there is a change in the feeding program. Over feeding is being practiced right from the day one of stocking in order to get maximum growth. Check trayfeeding percentage has come down from $1 \%$ of the feed to $0.2 \%$. Over feeding always causes water quality problems and causes stress to the cultured organisms. Stressed shrimp will exhibit poor immune response. On the other hand Shrimp breeding program focus on faster growth and these lines are less tolerant to stress. Opportunistic pathogens like vibrio naturally proliferate during stressful conditions aggravating the problem.

In the present study, from the Histopathological diagnosis and microscopic observations, we can conclude that any known viruses did not cause the IMS. Reduction of mortality on reduction of feed and stoking density indicate water quality and carrying capacity issues. Some opportunistic pathogens like Vibrio sp. naturally proliferate during stress conditions to aggravate the problem. There are incidences of RMS and WSSV causing severe mortalities. 
Basing on the present study observations and histopathological examination of the hepatopancreas of $L$. vannamei, we are intended to deliver some conclusive remarks as follows. For the sustainable aquaculture operations it is essential to procure high quality seed, followed by better pond management practices, biosecurity measures and health management of the shrimps during the entire culture period.

\section{References}

Amaro, C., Biosca, E.G., Fouz, B., Alcaide, E. and Esteve, C. 1995.Evidence that water transmits Vibrio vulnificus biotype 2 infections to eels.Applied Environmental Microbiology, 61(3): 1133-1137.

Baumann, P., Furniss, A.L. and Lee, J.V. 1984. Genus I. Vibrio pacini 1854. In: Bergyey's Manual of Systematic Bacterioloy, Krieg, N.R. and Holt, J.G. (Eds.). Williams and Wilkins, Baltimore, MD, 1: 518-538.

Chen, S.N., Huang, S.L. and Kou, G.H. 1992. Studies on the epizootics and pathogenicity of bacterial infections in cultured Giant Tiger prawn, Penaeusmonodon in Taiwan. In: Fulks, W. and Main, K.L. (Eds.)., Diseases of cultured Penaeid Shrimp in Asia and the United States. The Oceanic Institute, HI, 195-205 p.

Costa, R., Mermoud, I., Koblavi, S., Morlet, B., Haffner, P., Berthe, F., ... and Grimont, P. 1998. Isolation and characterization of bacteria associated with a Penaeusstylirostris disease (Syndrome 93) in New Caledonia. Aquaculture, 164(1-4): 297-309.

Frelier, P.F., Sis, R.F., Bell, T.A. and Lewis, D.H. 1992. Microscopic and ultrastructural studies of necrotizing hepatopancreatitis in Pacific white shrimp (Penaeusvannamei) cultured in
Texas. Veterinary Pathology, 29(4): 269-277.

Gomez-Gil, B., Tron-Mayen, L., Roque, A., Turnbull, J.F., Inglis, V. and GuerraFlores, A.L. 1998. Species of Vibrio isolated from hepatopancreas, haemolymph and digestive tract of a population of healthy juvenile Penaeusvannamei. Aquaculture, 163(12): $1-9$.

Gopal, S., Otta, S.K., Kumar, S., Karunasagar, I., Nishibuchi, M. and Karunasagar, I. 2005. The occurrence of Vibrio species in tropical shrimp culture environments; implications for food safety. International Journal of Food Microbiology, 102(2): 151-159.

Kannapiran, E., Ravindran, J., Chandrasekar, R. and Kalaiarasi, A. 2009. Studies on luminous, Vibrio harveyi associated with shrimp culture system rearing Penaeusmonodon. Journal of Environmental Biology, 30(5): 791-795. Lavilla-Pitogo, C.R., Baticados, M.C.L., Cruz-Lacierda, E.R. and de la Pena, L.D. 1990.Occurrence of luminous bacterial disease of Penaeusmonodon larvae in the Philippines. Aquaculture, 91(1-2): 1-13.

Lavilla-Pitogo, C.R., Leano, E.M. and Paner, M.G. 1998. Mortalities of pond-cultured juvenile shrimp, Penaeusmonodon, associated with dominance of luminescent vibrios in the rearing environment. Aquaculture, 164(1-4): 337-349.

Singh, I.B., Lakshmanaperumalsamy, P. and Chandramohan, D. 1998. Bacterial flora of pond reared Penaeusindicus (Milne Edwards). Journal of Aquaculture in the Tropics, 13: 133-142.

Sung, H.H., Hsu, S.F., Chen, C.K., Ting, Y.Y. and Chao, W.L. 2001.Relationships between disease outbreak in cultured tiger shrimp (Penaeusmonodon) and the composition of Vibrio communities in 
pond water and shrimp hepatopancreas during cultivation. Aquaculture, 192(24): 101-110.

Sung, H.H., Li, H.C., Tsai, F.M., Ting, Y.Y. and Chao, W.L. 1999. Changes in the composition of Vibrio communities in pond water during tiger shrimp (Penaeusmonodon) cultivation and in the hepatopancreas of healthy and diseased shrimp. Journal of Experimental Marine Biology and Ecology, 236(2): 261-271.

\section{How to cite this article:}

Nanjala Veerabhadra Rao and Avugaddi Satyanarayana. 2020. Running Mortality Syndrome (RMS)-A New Disease that Struck the Indian Shrimp Industry. Int.J.Curr.Microbiol.App.Sci. 9(01): 1928-1934. doi: https://doi.org/10.20546/ijcmas.2020.901.216 